\title{
Microbial Evaluation of Meat Contact Surfaces in Red Meat Abattoirs of Bauchi State, North-Eastern Nigeria
}

\author{
Shehu Abdul Qadir Zailani1 ${ }^{*}$, Mohammed Bello², Mashood Abiola Raji ${ }^{3}$, Junaidu Kabir², \\ Suleiman Maitala Yahuza ${ }^{4}$ \\ ${ }^{1}$ Department of Animal Health Technology, Bauchi State College of Agriculture, Bauchi State, Nigeria \\ ${ }^{2}$ Department of Veterinary Public Health and Preventive Medicine, Faculty of Veterinary Medicine, Ahmadu \\ Bello University, Zaria, Nigeria \\ ${ }^{3}$ Department of Veterinary Microbiology, Faculty of Veterinary Medicine, University of Ilorin, Ilorin, Kwara \\ State, Nigeria \\ ${ }^{4}$ Bacterial Zoonoses Laboratory, Department of Veterinary Public Health and Preventive Medicine, Faculty of \\ Veterinary Medicine, Ahmadu Bello University, Zaria, Nigeria \\ Email: "sazailani@hotmail.com
}

Received 25 November 2015; accepted 6 March 2016; published 9 March 2016

Copyright (C) 2016 by authors and Scientific Research Publishing Inc.

This work is licensed under the Creative Commons Attribution International License (CC BY).

http://creativecommons.org/licenses/by/4.0/

cc) (†)

\section{Open Access}

\begin{abstract}
Microbial quality (MQ) of meat contact surfaces (MCS) of six major abattoirs was evaluated with a subsequent further isolation and identification of $E$. coli 0157 . Two hundred and forty 240 swab samples (SS) from MCS that include cutting equipment, floor, tables and transport media were collected for total aerobic plate count and isolation of $E$. coli 0157 . Results of the SS indicated a mean value $7.1 \pm 0.3 \log _{10} \mathrm{cfu} / \mathrm{cm}^{2}$. A minimum value of $6.4 \pm 0.6 \log _{10} \mathrm{cfu} / \mathrm{cm}^{2}$ was recorded oncutting instrument from Ningi abattoir, while a maximum value of $7.8 \pm 0.3 \log _{10} \mathrm{cfu} / \mathrm{cm}^{2} \mathrm{was} \mathrm{ob-}$ tained from tables at Darazo abattoir. Only $3(1.2 \%)$ of the 240 SS of the MCS were positive for $E$. coli 0157 using the latex agglutination kit (Difco, Michigan, USA).
\end{abstract}

\section{Keywords}

Abattoirs, E. coli 0157, Meat Contact Surfaces, Microbial Quality

\section{Introduction}

The abattoir is a critical stage in the meat production continuum as it presents some of the best opportunities for ${ }^{*}$ Corresponding author.

How to cite this paper: Zailani, S.A.Q., Bello, M., Raji, M.A., Kabir, J. and Yahuza, S.M. (2016) Microbial Evaluation of Meat Contact Surfaces in Red Meat Abattoirs of Bauchi State, North-Eastern Nigeria. Open Journal of Medical Microbiology, 6, 3-8. http://dx.doi.org/10.4236/ojmm.2016.61002 
contamination. Generally speaking, biological, chemical and physical contaminants can all be encountered at an abattoir. The manner in which animals are slaughtered, eviscerated, dressed [1], and stored can affect the growth of pathogens and the potential for contamination of the meat by dirt, feces or other materials from animals, equipment and premises. The lack of hygienic practices by plant workers can also contaminate the carcasses or cause cross-contamination between different carcasses.

Meat has traditionally been viewed as a vehicle for a significant proportion of human food-borne disease. Although the spectrum of meat-borne diseases of public health importance has changed with changing production and processing systems, continuation of the problem has been well illustrated in recent years by human surveillance studies of specific meat-borne pathogens such as Escherichia coli O157:H7 [2].

Meat inspection is commonly perceived as the sanitary control of slaughter animals and meat. The aim of meat inspection is to provide safe and wholesome meat for human consumption. The responsibility for achieving this objective lies primarily with the relevant public health authorities who are represented by veterinarians and meat inspectors at the abattoir stage. In many developing regions and in particular in rural abattoirs, meat inspectors often lack the necessary information and guidelines to assess the sanitary status of carcasses, meat and organs from slaughter animals [3].

The consumer expects the meat he purchases to be safe and wholesome. Wholesome meat is produced hygienically, is pathogen free, retains its natural state and nutritive value, has optimum fat and is unconditionally acceptable to the consumer [4]. The location of abattoir shall be suitable i.e. distant from residential area that will cause danger, annoyance and damage to the person and one's property. The location of abattoir shall not be in a risk of flooding, land collapse causing construction damages [5].

For food safety reasons, the layout of an abattoir must provide for the prevention of cross contamination and adequate separation of incompatible activities. The construction of the building and the equipment used in abattoirs must prevent proper slaughter and processing, allow for ease of cleaning and sanitation and be properly maintained [1].

Every approved abattoir shall be supplied with electricity at a tension sufficient to provide adequate lighting, heating and cold storage, and water in sufficient quantity to comply with regulations made under this Act, and in any event shall be piped at a pressure of not less than 2 atmospheres. All water supplied to the abattoir shall meet the standard of portability required for human consumption in the urban areas [6].

Meat shall be inspected by a meat inspector or veterinary officer at the abattoir at the time of slaughter for the purpose of ascertaining whether it is fit for human consumption. In the event of any abnormal cutting or removal of parts before inspection the whole carcass may be seized and destroyed by the meat inspector after written notice to the owner or his agent in charge of the abattoir of his intention to do so, stating his reasons [6].

\section{Materials and Methods}

\subsection{Sampling}

A total of two hundred and forty (240) swab samples were collected from the six (6) major abattoirs under study. Ten (10) swab samples each were obtained from meat contact surfaces that include; cutting instruments, floor, table, and transport media, making a total of 40 samples from each of the abattoirs.

Commercially available sterile swabs contained in cotton-plugged covers and $5 \mathrm{mls}$ of sterile normal saline diluents in a screw-capped test tubes were used for the sample collection. A maximum of $100 \mathrm{~cm}^{2}$ of the desired meat contact surfaces such as knives, axe, tables, floors and meat transport media (head pan, wheel barrows, carts etc.) were swabbed. The sterile swab were removed and dipped in a diluents and excess saline removed by pressing against the inner side of the tube as described by [7].

The end of the swab that has been held will be broken-off using a sterile stainless steel scissors leaving the swab in the saline which is then covered tightly. The samples were labelled and taken to the laboratory in a cool box place promptly for processing and were not held for more than $12 \mathrm{~h}$.

\subsection{Laboratory Procedure}

The tubes containing the swabs were rocked to suspend the organisms; total plate counts were determined by dropping $0.1 \mathrm{ml}$ of the swab suspension onto a plate count Agar (Nutrient Agar) and spread uniformly with a sterile glass rod. The duplicate plates were allowed to solidify, inverted and incubated at $37^{\circ} \mathrm{C}$ for $24 \mathrm{hrs}$, therefore all organisms growing in plate agar whether on, within or below were counted and the average growth on 
the two plates were recorded. Serial dilutions of the original diluents containing the swabs were made earlier on made to 10 fold dilution with a dilution factor of $10^{6}$ to reduce the high surface contamination. The results obtained were expressed as bacterial colony forming units per centimetre square $\left(\mathrm{CFU} / \mathrm{cm}^{2}\right)$.

\subsection{Isolation and Identification of $E$. coli and $E$ c coli 0157}

Escherichia coli were isolated by plating the swab suspension samples on Eosin Methylene Blue (EMB, (Oxoid,U.K.)) using a sterile loop, incubated for $24 \mathrm{~h}$ at $37^{\circ} \mathrm{C}$ and colonies with characteristics greenish metallic sheen appearance on the EMB were further subjected to biochemical characterization as previously described by [8] and [9]. Isolates identified as E. coli were further tested on Cefixime Tellurite (Oxoid, UK)—Sorbitol MacConkey (CT-SMAC) agar (Oxoid, UK) and incubated for $18-24 \mathrm{~h}$ at $37^{\circ} \mathrm{C}$ for identification of colourless colonies which were recognized as non-sorbitol fermenters (NSF). The E. coli O157 strains were subsequently confirmed using E. coli O157 Antiserum (Difco, Michigan, USA) to observe for agglutination which is an indication of positive result.

The raw data obtained from the meat contact surfaces in the abattoirs viz; cutting instruments, floor, tables and transport media were processed using standard procedure as described by [8] where an average of the cfu/ $\mathrm{cm}^{2}$ values of the contact surfaces for the sample determined were transformed to log base $10\left(\log _{10}\right)$ then the mean standard deviation (SD) of the \% recovery of the $\log _{10}$ of the values were calculated as shown on Table 2 and Table 3.

\section{Results}

\section{Isolation and Identification of $E$. coli 0157}

The results on Table 1 below indicates that three (3) E. coli (O157) were isolated from the two hundred and forty (240) swab samples of meat contact surfaces from the six (6) major abattoirs of Bauchi state, the isolates obtained were specifically from cutting instrument, table and transport medium. While there was no isolation made from floor the samples.

Results of the total aerobic counts (Table 2) below showed that the highest value of CFU/ $\mathrm{cm}^{2}$ of the meat contact surfaces was $7.8 \pm 0.3$ obtained from tables at Darazo abattoir, while the lowest value of $6.4 \pm 0.6$ was obtained on cutting intruments from Ningi abattoir. Misau abattoir has the highest number of samples with nine (9) E. coli isolates while Katagum (Azare) has the least number of isolation i.e with only one (1) sample showing greenish metallic sheen.

The results (Table 3) below showed the average of total aerobic count of all the samples collected from the major abattoirs of the state where the highest value was found to be $7.4 \pm 0.3 \mathrm{CFU} / \mathrm{cm}^{2}$ and with $23.3 \%$ frequency of $E$. coli isolation from tables, while the lowest value of $7.2 \pm 0.2 \mathrm{CFU} / \mathrm{cm}^{2}$ and $6.7 \%$ frequency of isolation was recorded from transport media. The three (3) E. coli O157 were recorded from cutting instrument, table and transport media.

\section{Discussion}

The bacterial load for this research work is more than the recommended maximum permissible limit of aerobic plate count for raw meat stated by the International Commission on Microbiological Specifications for Food (ICMSF) of $6.7 \log _{10} \mathrm{cfu} / \mathrm{g}$. The research therefore, indicated that the various MCS surveyed were at a risk of contaminating the raw meat that comes in contact with the surfaces as such posing a risk of reducing the shelve life of the meat and a possibility of transmitting infections to the consumer. And the total aerobic count was found

Table 1. Frequency of isolation E. coli 0157 from MCS and water samples.

\begin{tabular}{ccc}
\hline Meat Contact Surfaces/Water Sample & Number of Samples & Positive for $\boldsymbol{E}$. coli O157 Agglutination Test \\
\hline Cutting Instruments & 60 & 1 \\
Floor & 60 & 0 \\
Table & 60 & 1 \\
Transport Media & 60 & 1 \\
& $\mathbf{2 4 0}$ & $\mathbf{3}$ \\
\hline
\end{tabular}


Table 2. Total aerobic plate (TAC) counts and rate of occurrence of E. coli isolated from the meat contact surfaces at the major abattoirs.

\begin{tabular}{|c|c|c|c|c|c|c|}
\hline $\begin{array}{l}\text { Abattoir } \\
\text { Location }\end{array}$ & $\begin{array}{c}\text { Contact Surfaces } \\
\text { Sampled }\end{array}$ & $\begin{array}{l}\text { No. of } \\
\text { Samples }\end{array}$ & $\begin{array}{c}\text { TAC } \log _{10} \text { CFU/cm } \\
\text { (Mean } \pm \text { SD) }\end{array}$ & $\begin{array}{l}\text { No. of Samples with } \\
\text { E. coli Isolate }\end{array}$ & $\begin{array}{c}\text { Frequency of } E \text {. coli } \\
\text { Isolation (\%) }\end{array}$ & $\begin{array}{c}\text { E. coli } \\
\text { O157 }\end{array}$ \\
\hline \multirow{4}{*}{ Bauchi } & Cutting Instruments & 10 & $7.1 \pm 0.2$ & 0 & 0 & - \\
\hline & Floor & 10 & $7.5 \pm 0.2$ & 2 & 20 & - \\
\hline & Table & 10 & $7.2 \pm 0.3$ & 2 & 20 & - \\
\hline & Transport Media & 10 & $7.4 \pm 0.1$ & 3 & 30 & - \\
\hline \multirow{4}{*}{ Dass } & Cutting Instruments & 10 & $7.6 \pm 0.1$ & 4 & 40 & + \\
\hline & Floor & 10 & $7.4 \pm 0.2$ & 0 & 0 & - \\
\hline & Table & 10 & $7.5 \pm 0.1$ & 4 & 40 & - \\
\hline & Transport Media & 10 & $7.2 \pm 0.2$ & 0 & 0 & - \\
\hline \multirow{4}{*}{ Darazo } & Cutting Instruments & 10 & $7.6 \pm 0.2$ & 0 & 0 & - \\
\hline & Floor & 10 & $7.6 \pm 0.2$ & 0 & 0 & - \\
\hline & Table & 10 & $7.8 \pm 0.3$ & 2 & 20 & + \\
\hline & Transport Media & 10 & $7.6 \pm 0.1$ & 0 & 0 & - \\
\hline \multirow{4}{*}{ Katagum } & Cutting Instruments & 10 & $6.9 \pm 0.7$ & 0 & 0 & - \\
\hline & Floor & 10 & $7.0 \pm 0.3$ & 0 & 0 & - \\
\hline & Table & 10 & $6.9 \pm 0.8$ & 0 & 0 & - \\
\hline & Transport Media & 10 & $7.1 \pm 0.2$ & 1 & 10 & - \\
\hline \multirow{4}{*}{ Misau } & Cutting Instruments & 10 & $7.5 \pm 0.2$ & 1 & 10 & - \\
\hline & Floor & 10 & $7.5 \pm 0.3$ & 2 & 20 & - \\
\hline & Table & 10 & $7.3 \pm 0.3$ & 3 & 30 & - \\
\hline & Transport Media & 10 & $7.4 \pm 0.3$ & 3 & 30 & - \\
\hline \multirow{4}{*}{ Ningi } & Cutting Instruments & 10 & $6.4 \pm 0.6$ & 0 & 0 & - \\
\hline & Floor & 10 & $6.9 \pm 0.8$ & 0 & 0 & - \\
\hline & Table & 10 & $7.4 \pm 0.2$ & 3 & 30 & - \\
\hline & Transport Media & 10 & $6.7 \pm 0.4$ & 5 & 50 & + \\
\hline
\end{tabular}

Key: TAC $=$ Total Aerobic Count.

Table 3. Summary of total aerobic plate (TAC) counts and rate of occurrence of E. coli isolated from the meat contact surfaces at the major abattoirs.

\begin{tabular}{cccccc}
\hline $\begin{array}{c}\text { Contact Surfaces } \\
\text { Sampled }\end{array}$ & $\begin{array}{c}\text { No. of } \\
\text { Samples }\end{array}$ & $\begin{array}{c}\text { TAC } \log _{10} \mathbf{C F U} / \mathbf{c m}^{2} \\
(\mathbf{M e a n} \pm \text { SD) }\end{array}$ & $\begin{array}{c}\text { No. of Samples with } \boldsymbol{E} \text {. } \\
\text { coli Isolate }\end{array}$ & $\begin{array}{c}\text { Frequency of } \boldsymbol{E} \text {. coli } \\
\text { Isolation (\%) }\end{array}$ & $\begin{array}{c}\boldsymbol{E} \text {. coli } \\
\mathbf{0 1 5 7}\end{array}$ \\
\hline Cutting Instruments & 60 & $7.2 \pm 0.3$ & 5 & 8.3 & + \\
Floor & 60 & $7.3 \pm 0.4$ & 4 & 6.7 & - \\
Table & 60 & $7.4 \pm 0.3$ & 14 & 23.3 & + \\
Transport Media & 60 & $7.2 \pm 0.2$ & 12 & 20 & + \\
\hline
\end{tabular}

to be between $6.4 \pm 0.6$ to $7.8 \pm 0.3 \log _{10} \mathrm{cfu} / \mathrm{cm}^{2}$ from cutting instrument and on table respectively, the result therefore indicates a very high level of bacterial contamination when compared to the 2.71 to $3.15 \log _{10} \mathrm{cfu} / \mathrm{cm}^{2}$ obtained from food contact surfaces in Istanbul, Turkey by [10] and the $6.7 \pm 5.3$ to $8.8 \pm 7.5 \log _{10} \mathrm{cfu} / \mathrm{cm}^{2}$ obtained by [11] from meat processing plant in Russia, all the the two situations can be attributed to an improved sanitary conditions when compared to the dilapidated and obselete conditions found in the abattoirs under study.

Moreover, it was also clearly indicated that the bacterial load was higher on the tables when compared to the other three MCS from all the abattoirs with values range of $6.9 \pm 0.8-7.8 \pm 0.3 \log _{10} \mathrm{cfu} / \mathrm{cm}^{2}$ (and a mean value of $7.4 \pm 0.3 \log _{10} \mathrm{cfu} / \mathrm{cm}^{2}$ ) and this can be attributed to improper cleaning/washing or disinfection of the table surface in relation to all the other MCSs, as well as the possibility of biofilms developing on the tables. 


\section{Conclusion}

The results of the study indicated that the MQ of the MCS examined were found to be very high and the examined surfaces heavily contaminated, and that the meat inspection services were virtually absent in all the visited abattoirs as such there was no any documented record of diseases encountered at ante mortem examination or post mortem inspection in the abattoirs. E. coli $\mathrm{O} 157$ was isolated from bacterial organisms that contaminate the MCS and tables were found to have more bacterial load compared to the other MCS examined. Bacterial contamination has continue to be a major challenge to meat safety as it reduces the shelve life of the meat and poses a danger of transmitting diseases to the consumers. It was also very clearly manifested that there were no disinfectants used at the various abattoirs either for washing the MCS before and after the daily operations or for disinfecting hands of the butchers and personnel.

\section{Recommendation}

We therefore recommended that the Bauchi state Government should implement a continuing education and a training programme for meat inspectors and the butchers on regular basis, to enable them understand the significance of maintaining cleanliness during the abattoir operations. And there should be increased number of veterinarians and livestock superintendents at the various abattoirs for proper implementation of meat inspection procedures. The involvement of professional organizations such as the Nigerian Veterinary Medical Association (NVMA) in the management of the abattoirs will help in implementation of rules and regulations relating to abattoir operations. And finally that all the abattoirs that require renovations and or relocations or supply of equipment should be carried out with immediate effect.

Certain measures to prevent meat contamination and to ensure only safe and wholesome meat are delivered to consumer include but not restricted to the following as described in [12]; frequent approval and monitoring of water used in the processing of meat such that water must be clean and satisfy the standard of water for human consumption. Improving the cleanliness of the MCSs and any other surfaces that comes in direct or indirect contact with the meat. Preventing cross-contamination of raw meat from ready-to-eat food within, around or outside the abattoirs. Meat must be free from adulteration from microbial, chemical or physical contaminants such as pesticides, fuel, lubricants, insanitary materials etc. And finally the health conditions of employee must be controlled to prevent persons who are diagnosed with or have illness, wounds etc to be source of microbial contamination to the meat

\section{References}

[1] Ontario (1995) Report of Meat Regulatory and Inspection Review, Ch. 6, 256.

[2] Codex Alimentarius (2005) Code of Hygiene Practice for Meat (CAC/ RCP 58-2005). www.fao.org/fao...codexalimentarius/...of.../en/?...CAC/RCP

[3] Manual (2006) Manual on Meat Inspection for Developing Countries Reprinted 2000. http://www.fao.org/003/t0756e00.htm

[4] Govindarajan, C.V. (1990) Maintenance of Hygienic and Sanitary Conditions Including Personal Hygiene in the Meat Factory. Technical Paper in First National Seminar on Marketing of Meat Food Products in India, Aligarh.

[5] TAS (2004) Good Manufacturing Practices for Abattoir, Thai Agricultural Standard TAS 9004-2004, Published in the Royal Gazette Vol. 122 Special Section 64d, Dated 11 August b.e.2548 (2005).

[6] Abattoir Act [Cap 99] (1988) Laws of the Republic of Vanuata, Revised Edition 1988, Abattoirs Vanuata Consolidated Legislation.

[7] Ajogi, I., Okolocha, E.C., Luga, I.I., Dzikwi, A.A., Egege, S.C., Umoh, J.U., Adesiyun, A.A., Aganga, A.O., Du-Sai, D.H.M., Ezeifeka, G.O., Kwaga, J.K.P., Lombin, L.H., Mosimabale, F.O. and Oni, O.O. (2005). A Manual for Clinics in Veterinary Public Health and Preventive Medicine. Prepared by the Department of Veterinary Public Health and Preventive Medicine, Ahmadu Bello University, Zaria. S. Asekome \& Co, Zaria, 15-20

[8] Barrow, G.I. and Feltham, R.K.A. (1993) Cowan and Steel’s Manual for the Identification of Medical Bacteria. 3rd Edition, 135.

[9] Macfaddin, J.F. (1977) Biochemical Tests for Identification of Medical Bacteria. Williams and Wilkins, New York.

[10] Cetin, O., Kahraman, T. and Kemal, B.S. (2006) Microbiological Evaluation of Food Contact Surfaces at Red Meat Processing Plants in Istanbul, Turkey. Italian Journal of Animal Science, 5, 277-283 
[11] Bello, M. and Son, K.N. (2009) Assessment of Microbial Load from Meat Contact Surfaces and Isolation of Enteropathogenic E. coli at a Meat Processing Plant, Russia. Nigerian Veterinary Journal, 30, 1-8.

[12] Meat and Poultry Safety (1994) New York Department of Agriculture and Markets in Conjunction with United State Department of Agriculture an Amended Federal meat and Poultry Inspection Regulations. 